and we all have many gaps in our knowledge of and feeling for it. Such gaps are particularly noticeable as we move within the mother-tongue to areas either geographically or historically remote. Yet even when we move to such remote areas, certain rhythms, associations of words, patterns of syntax, will still to some extent be common ground, to be entered on as a landowner might walk on a little-visited part of his own estate; strange and often puzzling, but with a certain generic if partial familiarity. The Lord's Prayer, for example, in Old, Middle and Modern English, even in the New English $B i b l e$, achieves an instant recognition.

We are led to a modification of our earlier statement that the Englishness of English literature has been dissolved. The Englishness of English literature does not derive from shared nationhood or values; it derives first of all from the language. But further, no full account of the language can be given, no complete sense of its character, richness or potentiality grasped or aimed at, if the literature created in that language is ignored.

\section{The Common Core}

Since the language determines something of the general nature of the literature it will also give a lead as to what literature should be studied.
Language is an historical phenomenon and in order to be properly understood needs to be known in its historical depth. The same is true for the literature of a language. Since in order to define the Englishness of English literature we shall not be looking for some literary quintessence common to every example, we must seek to understand the relationships of works of literature to other works, to the authors, the general conditions of life over a period of time.

Practical considerations must enter here. The kind of selection of literature which is made will vary in different parts of the world according to the angle of approach and the special needs and interests of readers. Nevertheless, English literature only itself can define its Englishness: it is English, and agreement should be reached on what is nowadays best called 'the common core'. Recognition of this common core should be independent of special interests and different approaches. I cannot see how that common core can be other than that section of English literature which was noted earlier as the least controversially 'English' in the strict sense of the word; as literature emanating from England before the twentieth century.

Let us sum it up crudely as that major literature written in English in England during the period from Chaucer to Dickens. Within this period are many authors self-evidently of major importance, but the outstanding author is Shakespeare. The Englishness of English literature depends greatly on him. There are many major authors and texts before Chaucer and after Dickens and they should be studied, but considerations of special connections, special interests, particular lines of approach, varying requirements in various parts of the world will both lead to selection of material and ensure that this selection will vary greatly. Clearly, the nineteenth and twentieth centuries will attract most attention. But a common core, a common ground of interest is vital to the cohesion of the subject.

How English then is English literature? Not at all, in terms of possession, loyalty, nationhood. Those qualities exist and for some of us will naturally lead to and effect our understanding of English literature. But not everyone will be so affected. The Englishness of English literature is determined by the English language, and those texts of literary worth written in that language. The texts themselves, in all their variety, with all their connections, define the Englishness of English literature. They exist as an autonomous body of material extending widely through time and space, like the Himalayas, including many different attitudes and ecological systems, where many people can walk or climb in many different parts, but which are recognisable as a single range, with Shakespeare our Mount Everest, fortunately much less formidable.

\title{
NEWS
}

\section{Language Bar}

Because of a shortage of Welshspeaking staff in Welsh schools and ancilliary services, young children whose first language is Welsh 'are being classified as backward and even educationally subnormal' (Tony Heath, The Observer, 20 May 84). Since the toddlers are tested in English, a specific language difficulty 'may be interpreted as a learning problem, leading to wrong classification and low IQ ratings.'

Welsh is the language of the home for many of the Principality's half a million speakers of the language, so that the contact with English may be minimal for many children before their first day at school. The Welsh Office, however, aware that the issue is as political as it is social and linguistic, has sponsored projects at the university colleges of Aberystwyth and Bangor to develop more test materials in Welsh. But, says Heath, 'progress in the key area - the ability of staff to speak the language and communicate effectively with parents as well as children - is slight'.

In addition, attitudes on the part of educational and health administrators are not always helpful and occasionally border on the insulting. Heath reports: 'Mrs Enfys Llwyd, who lives near Cardigan, is the mother of a 20-month-old baby boy currently being assessed for multiple problems. She said yesterday: "When I told the receptionist at the local assessment centre that he was called Owain, she replied: 'Is he a Welsh Nationalist then? He'll have to learn English'."

'Paradoxically, the further Mrs Lloyd (sic) goes with her son from the Welsh heartlands, the greater the understanding she receives. "At the Heath Hospital in Cardiff they were very good and when we went to Great Ormond Street in London we were offered the services of a translator," she said.' 